\title{
Pengaruh Profitabilitas, Leverage, Komisaris Independen, Kepemilikan Institusional, dan Ukuran Perusahaan terhadap Penghindaran Pajak pada Perusahaan Manufaktur yang Terdaftar di Bursa Efek Indonesia pada Tahun 2014-2018
}

\author{
Novita Sari $^{1}$, Elvira Luthan ${ }^{2}$, Nini Syafriyeni ${ }^{3}$ \\ ${ }^{1}$ Student of Magister Degree of Accounting, Andalas University \\ ${ }^{2}$ Lecture of Accounting Department, Andalas University \\ ${ }^{3}$ Lecture of Accounting Department, Andalas University \\ Correspondence email: Novitasari28111994@gmail.com
}

\begin{abstract}
Abstrak. Sumber pendapatan negara terbesar berasal dari sektor perpajakan dan pemerintah Indonesia terus berusaha untuk meningkatkan langkah optimalisasi penerimaan pajak demi memaksimalkan penerimaan atas sektor ini. Namun sampai saat ini banyak warga negara yang masih menganggap pajak sebagai suatu beban. Perusahaan atau badan usaha juga masih menganggap pajak sebagai beban yang akan mengurangi laba bersihnya. Wajib pajak akan cenderung mencari cara untuk memperkecil pajak yang harus dibayar, salah satunya dengan pratek tax avoidance. Praktek tax avoidance merupakan hal yang tidak melanggar hukum (legal), namun disisi lain tax avoidance tidak diinginkan oleh pemerintah karena akan mengurangi pendapatan bagi negara. Tujuan dari penelitian ini adalah untuk menganalisis pengaruh profitabilitas, leverage, proporsi komisaris independen, kepemilikan institusional, dan ukuran perusahaan terhadap tax avoidance. Populasi penelitian ini adalah seluruh perusahaan manufaktur yang terdaftar di Bursa Efek Indonesia (BEI) selama periode 2014-2018. Pemilihan sampel menggunakan metode non probability sampling dengan teknik purposive sampling. Analisis data menggunakan uji asumsi klasik yaitu uji normalitas, uji multikolinieritas, uji heteroskedastisitas, dan uji autokorelasi, serta pengujian hipotesis menggunakan analisis regresi berganda. Hasil penelitian memperlihatkan bahwa terdapat pengaruh antara profitabilitas dan proporsi dewan komisaris independen terhadap tax avoidance, sementara variabel leverage, kepemilikan institusional dan ukuran perusahaan tidak menunjukkan pengaruh pada tax avoidance.
\end{abstract}

Kata kunci: Leverage; Kepemilikan Institusional; Komisaris Independen; Profitabilitas; Tax Avoidance; Ukuran Perusahaan

\begin{abstract}
The biggest source of state income comes from taxes. So the Indonesian government continues to strive to improve tax revenue optimization measures to maximize revenue from the tax sector. But until now many citizens still consider tax as a burden. The company or entity still considers tax as an expense that will reduce the company's net profit. Taxpayers will tend to look for ways to reduce the tax they pay, both legally and illegally, one of which is the practice of tax avoidance Tax avoidance is a complex and unique problem because on one hand tax avoidance does not violate the law, on the other hand tax avoidance is not wanted by the government because it reduces income for the country. The purpose of this study is to analyze the effect of profitability, leverage, the proportion of independent commissioners, institutional ownership, and company size, on tax avoidance. The population of this research is the entire manufacturing company registered in indonesia stock exchange (BEI) 2014-2018 during the period.A method of sampling nonprobability using methods with techniques of sampling purposive sampling .The technique of analysis of data using the test is the classic normality, multikolinieritas, heteroskedastisitas test, and autokorelasi test. Testing the hypothesis of the use of regression analysis double. The results of the study show that there is an influence between profitability and the proportion of independent commissioners on tax avoidance, while the variable leverage, institutional ownership and firm size do not show an influence on tax avoidance.
\end{abstract}

Keyword: Firm Size; Independent Commissioners; Leverage; Profitability; the Institutional Ownership; and, Tax Avoidance

\section{PENDAHULUAN}

Berdasarkan pasal 21 Undang-Undang Nomor 28 Tahun 2007 tentang Ketentuan Umum dan Tata Cara Perpajakan menyebutkan bahwa pajak merupakan kontribusi wajib kepada negara yang terhutang oleh orang pribadi atau badan yang bersifat memaksa berdasarkan Undang-Undang, dengan tidak mendapatkan imbalan secara langsung dan digunakan untuk keperluan negara bagi sebesar-besarnya kemakmuran rakyat

Salah satu upaya pemerintah untuk meningkatkan penerimaan pajak adalah dengan selalu berupaya untuk melakukan perbaikan dan penyempurnaan atas peraturan perpajakan di Indonesia. Perubahan peraturan perpajakan yang dilakukan oleh pemerintah untuk memperbaiki sistem perpajakan dan meningkatkan jumlah penerimaan negara di bagian perpajakan ini disebut dengan reformasi pajak. Masih banyak warga negara yang menganggap pajak sebagai suatu beban. Perusahaan atau badan juga masih menganggap pajak sebagai beban yang akan mengurangi laba bersih perusahaan. Wajib pajak akan cenderung mencari cara untuk memperkecil pajak yang mereka bayar, baik secara legal maupun ilegal, salah satunya adalah dengan 
Novita Sari et al, Pengaruh Profitabilitas, Leverage, Komisaris Independen, Kepemilikan Institusional, dan Ukuran Perusahaan terhadap Penghindaran Pajak pada Perusahaan Manufaktur yang Terdaftar di Bursa Efek Indonesia pada Tahun 2014-2018

pratek tax avoidance atau penghindaran pajak (Sartika, 2012).

Apabila dilihat dari sisi wajib pajak, selama wajib pajak pribadi ataupun badan memiliki cara dalam meminimalkan pajak dan belum ada peraturan yang pasti tentang pelanggaran pajak, maka hal yang dilakukan sah-sah saja atau legal. Sedangkan dari pihak pemerintah yaitu peraturan yang ada dalam hal pembayaran perpajakan diharapkan tidak disalahgunakan dengan cara penghindaran perpajakan atau dengan meminimalkan pajak perusahaan demi memperoleh keuntungan. Sifat tax avoidance yang sah menurut hukum membuat pemerintah tidak dapat menjatuhkan sanksi bahkan ketika ada indikasi skema tax avoidance akan dilakukan oleh perusahaan.

Berdasarkan penelitian terdahulu seperti Darmawan and Sukartha (2014), Dewi, (2017), Rinaldi and Cheisviyanny (2015) profitabilitas merupakan salah satu faktor yang dapat mempengaruhi dalam melakukan praktek penghindaran pajak. Salah satu pengukuran profitabilitas yang sering digunakan yaitu dengan menggunakan Return On Asset (ROA).

Selain profitabilitas, leverage juga dapat diprediksi sebagai faktor yang mempengaruhi tax avoidance. Leverage merupakan tingkat hutang yang digunakan perusahaan dalam melakukan pembiayaan. Debt to Equity Ratio (DER) merupakan rasio yang mengukur seberapa jauh perusahaan dibiayai oleh hutang dan kemampuan perusahaan untuk memenuhi kewajibannya dengan ekuitas yang dimiliki. Beberapa peneliti seperti Zahirah (2017), Agusti, (2013), Nursari, et al (2017), Wijayanti and Budi N, (2017), menemukan bahwa leverage berpengaruh positif terhadap tax avoidance, sementara itu beberapa peneliti lain menyatakan bahwa leverage berpengaruh negatif terhadap tax avoidance seperti pada penelitian Dewi, (2017), Rinaldi and Cheisviyanny (2015), Dharma, I. M. S., (2016), Sukartha (2015).

Menurut Zarkasyi, M. (2008) terdapat empat mekanisme corporate Governance, di antaranya: komisaris independen, kepemilikan institusional, kualitas audit, dan dewan direksi. Pada penelitian ini penulis memfokuskan untuk menggunakan 2 mekanisme penelitian yang ada didalam corporate governance yaitu proporsi dewan komisaris independen dan kepemilikan institusional, hal ini dikarenakan proporsi dewan komisaris independen dan kepemilikan institusional mengambil peran yang cukup besar dalam aktivitasaktivitas perusahaan sehingga sangat berpengaruh terhadap kebijakan dalam pengambilan keputusan perusahaan yang kemudian akan berpengaruh besar terhadap kebijakan pajak agresif suatu perusahaan.

Beberapa penelitian terdahulu menemukan bahwa komisaris independen memiliki hasil yang tidak konsisten, seperti pada penelitian Maharani dan Suardana (2014), Sandy dan Lukviarman (2015),
Rachmithasari (2015), Wijayanti (2017), Windarni et al (2018) menemukan bahwa proporsi dewan komisaris berpengaruh negatif terhadap tax avoidance artinya semakin baik pengawasan komisaris independen terhadap suatu perusahaan, maka praktik tax avoidance pada perusahaan itu dapat semakin berkurang. Sementara menurut Sunarsih and Oktaviani, (2016), Winata (2014), Marfirah dan SyamBZ, (2016), Putranti dan Setiawanta (2015) menemukan bahwa komisaris independen berpengaruh positif terhadap tax avoidance. Artinya semakin baik pengawasan yang dilakukan komisaris independen terhadap suatu perusahaan, maka praktik tax avoidance pada perusahaan itu dapat semakin meningkat.

Penelitian yang dilakukan oleh Nursari et al, (2017), Muhammad Fajar (2018), Agustina and Aris, (2016), Azizah Zahirah (2017), Pohan (2019) mengenai hubungan kepemilikan institusional dan tax avoidance menunjukkan berpengaruh positif.. Sedangkan penelitian menurut Putranti dan Setiawanta (2015), Merslythalia dan Lasmana (2016), Bahri et al. (2015), Sihaloho dan Pratomo (2015), Alviyani and Surya (2016) menyatakan bahwa kepemilikan insitiusional berpengaruh negatif terhadap tax avoidance.

Faktor lainnya yang juga menjadi faktor penentu dalam penghindaran pajak adalah ukuran perusahaan. Ukuran perusahaan dapat dilihat dari total aset yang dimiliki oleh suatu perusahaan. Ukuran perusahaan merupakan suatu skala dimana besar kecilnya perusahaan yang dapat diklasifikasikan dalam berbagai cara, seperti log total aktiva, log total penjualan dan kapitalisasi pasar (Handayani dan Wulandari, 2014).

Perusahaan besar cenderung memiliki sumber daya yang lebih besar dibandingkan perusahaan kecil dalam melakukan pengelolaan pajak. Laba yang besar dan stabil yang dimiliki perusahaan berukuran besar cenderung mendorong perusahaan untuk melakukan kegiatan penghindaran pajak. Hal tersebut sesuai dengan penelitian yang dilakukan oleh Surbakti, (2012), Dewinta dan Setiawan (2016), Dharma, (2016) serta Siregar Rifka (2016) yang menyatakan bahwa ukuran perusahaan berpengaruh positif pada penghindaran pajak. Berbeda dengan penelitian yang dilakukan oleh Puspitasari, (2014), Nurlaily (2017), Dewi (2017), Kurniasih dan Ratna Sari, (2013) yang menyatakan bahwa ukuran perusahaan berpengaruh negatif pada tax avoidance.

Persoalan tax avoidance merupakan persoalan yang rumit dan unik karena disatu sisi tax avoidance tidak melanggar hukum (legal), namun disisi lain tax avoidance tidak diinginkan oleh pemerintah karena mengurangi pendapatan bagi negara. Berdasarkan permasalahan diatas, dikaitkan dengan hasil penelitian sebelumnya dengan teori yang ada dan dengan belum konsistenya hasil penelitian yang terdahulu, maka penulis terdorong melakukan pengujian kembali untuk 
mengetahui faktor-faktor yang mempengaruhi tax avoidance. Hasil dari pengujian nantinya diharapkan dapat memberikan gambaran yang lebih baik tentang pengaruh profitabilitas, leverage, corporate governance dan ukuran perusahaan terhadap tax avoidance.

Penelitian ini merupakan replikasi dari penelitian sebelumnya, yang membedakan penelitian ini dengan penelitian sebelumnya adalah pada tahun penelitian dan pengukuran tax avoidance, dimana pada peneltian sebelumnya menggunakan Cash ETR, sementara alat ukur tax avoidance yang penulis gunakan adalah Book Tax Different (BTD). BTD merupakan proksi yang menggambarkan selisih antara laba akuntansi dengan laba fiskal. Keunggulan BTD dibandingkan menggunakan alat ukur lain adalah BTD memperlihatkan bagaimana perusahaan akan berusaha melaporkan laba akuntansi yang tinggi untuk kepentingan pemegang saham, namun melakukan strategi agar laba kena pajak menjadi rendah. BTD dapat menggambarkan strategi penghindaran pajak jangka panjang dan jangka pendek (Rego and Wilson, 2011). Melalui penelitian ini diharapkan masyarakat dapat mengetahui bahwa penghindaran pajak (tax avoidance) merupakan salah satu cara yang dapat merugikan pendapatan negara. Dimana pajak merupakan sumber pendapatan negara, sehingga jika wajib pajak banyak melakukan praktek tax avoidance, maka hal tersebut akan berdampak pada penurunan kesejahteraan masyarakat itu sendiri.

Penelitian ini juga berguna untuk memberikan gambaran yang lebih luas tentang pola perkembangan perusahaan-perusahaan yang melakukan penghindaran pajak, khususnya untuk perusahaan manufaktur. Pemilihan perusahaan manufaktur didasari atas pertimbangan bahwa aktivitas usaha perusahaan manufaktur sebagian besar dengan perpajakan. Perusahaan manufaktur merupakan penyumbang penerimaan pajak negara terbesar selain industri perdagangan, keuangan dan pertanian. Sepanjang 2018, penerimaan pajak dari sektor manufaktur ini tercatat tumbuh 17,1 persen. Industri pengolahan terus menjadi kontributor tertinggi terhadap penerimaan $\mathrm{PPh}$ nonmigas, di mana tahun ini mencapai 31,8 persen. Selanjutnya, diikuti sektor perdagangan 19,3 persen, jasa keuangan 14,0 persen, dan pertanian 1,7 persen (kemenperin.go.id). Selain itu perusahaan manufaktur beberapa kali masuk sebagai wajib pajak yang difokuskan dalam daftar pemeriksaan Direktorat Jenderal Pajak, karena berdasarkan survei pada tahun 2012 terdapat 4000 perusahaan perusahaan penanaman modal asing yang melaporkan pajaknya namun tidak memiliki besaran pajak yang terhutang karena mengalami kerugian selama tujuh (7) tahun berturutturut dan perusahaan tersebut bergerak dibidang manufaktur (Prakosa, 2014)

\section{METODE \\ Jenis Penelitian}

Penelitian ini merupakan penelitian kuantitatif. Data yang diperoleh dari sampel populasi penelitian dianalisis sesuai dengan metode statistik yang digunakan kemudian diinterpretasikan.

Penelitian ini menggunakan data panel, Dimana data yang digunakan dalam penelitian ini yaitu data laporan keuangan perusahaan manufaktur yang terdaftar di Bursa Efek Indonesia tahun 2014-2018. Berdasarkan sumber datanya, data yang digunakan dalam penelitian ini adalah data sekunder. Dalam penelitian ini data diperoleh dari website resmi Bursa Efek Indonesia periode 2014-2018.

Tabel 1. Pengukuran Variabel

\begin{tabular}{|c|c|c|}
\hline No & Variabel & Konsep Variabel \\
\hline 1 & Tax avoidance $(Y)$ & $\begin{array}{l}\text { Kemampuan perusahaan dalam mengelola pajaknya, semakin } \\
\text { besar nilai Tax avoidance ini mengindikasikan semakin } \\
\text { rendah tingkat penghindaran pajak perusahaan. (Siahaan, } \\
\text { 2012) }\end{array}$ \\
\hline 2 & Profitabilitas $\left(\mathrm{X}_{1}\right)$ & $\begin{array}{l}\text { ROA adalah perbandingan antara laba bersih dengan total } \\
\text { asset pada akhir periode, yang digunakan sebagai indikator } \\
\text { kemampuan perusahaan dalam menghasilkan laba (Hanafi, } \\
\text { M., 2003) }\end{array}$ \\
\hline 3 & Leverege $\left(\mathrm{X}_{2}\right)$ & $\begin{array}{l}\text { Rasio yang menunjukkan besarnya hutang yang dimiliki oleh } \\
\text { perusahaan untuk membiayai aktivitas operasinya } \\
\text { (Darmawan and Sukartha, 2014). }\end{array}$ \\
\hline 4 & $\begin{array}{l}\text { Dewan komisaris } \\
\text { independen }\left(\mathrm{X}_{3}\right)\end{array}$ & $\begin{array}{l}\text { Proporsi dewan komisaris independen merupakan seorang } \\
\text { yang tidak terafiliasi dalam segala hal dengan pemegang } \\
\text { saham pengendali, tidak memiliki hubungan afiliasi dengan } \\
\text { direksi atau dewan komisaris serta tidak menjabat sebagai } \\
\text { direktur pada suatu perusahaan yang terkait dengan } \\
\text { perusahaan pemilik menurut peraturan yang dikelurkan oleh } \\
\text { BEI (Cahyono et al., 2016). }\end{array}$ \\
\hline
\end{tabular}

\section{Indikator}

Book Tax Different (BTD)= Laba

Akuntansi-Laba Fiskal/ Total

Aset

$\mathrm{ROA}=$ Net Income/ Total Asset

$\mathrm{DER}=$ Total Liabilities $/$ Total Equity

Jumlah dewan komisaris independen/ jumlah komisaris keseluruhan 
Novita Sari et al, Pengaruh Profitabilitas, Leverage, Komisaris Independen, Kepemilikan Institusional, dan Ukuran Perusahaan terhadap Penghindaran Pajak pada Perusahaan Manufaktur yang Terdaftar di Bursa Efek Indonesia pada Tahun 2014-2018

5 Kepemilikan Kepemilikan institusional merupakan lembaga yang memiliki institusional $\left(\mathrm{X}_{4}\right) \quad$ kepentingan besar terhadap investasi yang dilakukan Jumlah saham dimiliki insitusi/ termasuk investasi saham di dalam suatu perusahaan (Cahyono et al., 2016).

6 Ukuran

Ukuran perusahaan merupakan suatu pengklasifikasian jumlah saham beredar

Perusahaan $\left(\mathrm{X}_{5}\right) \quad$ sebuah perusahaan berdasarkan jumlah aset yang dimilikinya.Aset dinilai memiliki tingkat kestabilan yang cukup berkesinambungan (Kurniasih and Ratna Sari, 2013).

\section{Populasi dan Sampel}

Populasi dalam penelitian ini adalah perusahaan manufaktur yang terdaftar di Bursa Efek Indonesia pada tahun 2014-2018

Sampel dipilih dari populasi perusahaan berdasarkan purposive sampling. Periode penelitian adalah tahun 2014-2018. Pemilihan sampel menggunakan metode purposive sampling dengan kriteria sebagi berikut:

a. Perusahaan menerbitkan laporan keuangan secara rutin selama tahun 2014 - 2018.

b. Perusahaan memiliki laba positif.

c. Perusahaan memiliki data keuangan yang dibutuhkan untuk penelitian seperti Tax Avoidance, Profitabilitas, Laverage, Proporsi Dewan Komisaris Independen, Kepemilikan Institusional, dan Ukuran perusahaan .

d. Perusahaan menyajikan laporan keuangan dengan menggunakan mata uang Indonesia.

\section{Metode Analisis Data}

Metode analisis data dapat diartikan sebagai upaya mengolah data menjadi informasi, sehingga karakteristik atau sifat-sifat data tersebut dapat dengan mudah dipahami dan bermanfaat untuk menjawab masalahmasalah yang berkaitan dengan kegiatan penelitian (Sekaran, 2011). Metode analisis data dalam penelitian ini menggunakan bantuan program SPSS 20. Adapun alat analisis yang digunakan adalah analisis regresi linier berganda dengan melakukan uji asumsi klasik terlebih dahulu.

\section{Pengujian Hipotesis}

a. Uji F (uji model)

b. Koefisien Determinasi $\left(R^{2}\right)$

c. Uji t (uji parsial)

\section{HASIL DAN PEMBAHASAN} Analisis Statistik Deskriptif

Tabel 2. Statistik Deskriptif

\begin{tabular}{|c|c|c|c|c|c|c|}
\hline & Tax Avoidance & ROA & Leverage & Komisaris Independen & Kepemilikan Institusional & Size \\
\hline Mean & 0,02379 & 0,07286 & 0,66738 & 0,37476 & 0,67106 & 14,81588 \\
\hline Std. Deviation & 0,015217 & 0,04993 & 0,442501 & 0,066186 & 0,209047 & 1,811570 \\
\hline Minimum & 0,001 & 0,001 & 0,083 & 0,200 & 0,099 & 11,804 \\
\hline Maximum & 0,061 & 0,264 & 1,955 & 0,600 & 0,963 & 20,592 \\
\hline
\end{tabular}

Sumber: Data diolah

Tabel 2 menunjukkan hasil dari uji statistik deskriptif terhadap perusahaan sampel selama tahun 2014-2018 dengan nilai N (jumlah sampel) sebesar 192 . Dari analisis di atas, maka dapat disimpulkan deskriptif masing-masing variabel adalah sebagai berikut:

1. Tax avoidance (TA) memiliki nilai minimum sebesar 0,001 dari 192 sampel yang digunakan. Nilai maksimum tax avoidance sebesar 0,061 yang berarti nilai tertinggi terjadinya praktek tax avoidance pada beberapa sampel perusahaan adalah $6,1 \%$, dengan nilai rata-rata terjadinya praktek tax avoidance sebesar 2,3\%. Sedangkan standar deviasi memiliki nilai sebesar 0,01522 yang berarti bahwa ukuran penyebaran data dari variabel tax avoidance adalah sebesar 0,01522 dari 192 sampel yang digunakan. Standar deviasi yang lebih kecil dari nilai rata-rata menunjukkan kecilnya simpangan data variabel tax avoidance selama periode pengamatan.

2. ROA memiliki nilai minimum sebesar 0,001 berarti beberapa sampel perusahaan memiliki ROA paling sedikit sebesar 0,001. Nilai maksimum sebesar 0,26 yang berarti nilai ROA pada beberapa sampel perusaahaan paling banyak adalah $26 \%$, dengan nilai rata-rata sebesar 0,0729. Sedangkan standar deviasi memiliki nilai sebesar 0,04993 yang berarti bahwa ukuran penyebaran data dari variabel ROA sebesar 0,04993 dari 192 sampel yang digunakan

3. Leverage memiliki nilai minimum sebesar 0,08 yang berarti tingkat leverage pada beberapa sampel perusaahaan paling sedikit adalah $8 \%$. Nilai maksimum sebesar 1,95 yang berarti nilai leverage pada beberapa sampel perusaahaan paling banyak adalah 195\%, dengan nilai rata-rata sebesar 0,6674. Sedangkan standar deviasi memiliki nilai sebesar 0,44250 yang berarti bahwa ukuran penyebaran data dari variabel leverage sebesar 0,44250 dari 192 sampel yang digunakan.

4. Komisaris independen memiliki nilai minimum sebesar 0,20 dan nilai maksimum komisaris independen sebesar 0,60 yang berarti jumlah komisaris independen yang paling sedikit dari beberapa sampel perusahaan ada 2 sementara yang 
terbanyak dari beberapa sampel perusahaan adalah 6, dengan nilai rata-rata komisaris independen pada sampel perusahaan sebesar 0,3748. Sedangkan standar deviasi memiliki nilai sebsesar 0,06619 yang berarti bahwa ukuran penyebaran data dari variabel komisaris independen adalah sebesar 0,06619 dari 192 sampel yang digunakan.

5. Kepemilikan institusional memiliki nilai minimum sebesar 0,09 yang berarti tingkat kepemilikan institusional pada beberapa sampel perusaahaan paling sedikit adalah 9\%. Nilai maksimum kepemilikan institusional sebesar 0,963 yang berarti tingkat kepemilikan institusional beberapa sampel perusahaan paling tinggi adalah sebesar 96,3\%, dengan nilai rata-rata kepemilikan institusional sampel perusahaan sebesar 0,6711. Sedangkan standar deviasi memiliki nilai sebesar 0,20905 yang berarti bahwa ukuran penyebaran data dari variabel kepemilikan institusional sebesar 0,20905 dari 192 sampel yang digunakan.

6. Size memiliki nilai minimum sebesar 11,80 dan nilai maksimum sebesar 20,59, dengan nilai rata-rata sebesar 14,8159. Sedangkan standar deviasi memiliki nilai sebesar 1,81157 yang berarti bahwa ukuran penyebaran data dari variabel size sebesar 1,81157 dari 192 sampel yang digunakan. Standar deviasi yang leih besar dari nilai rata-rata menunjukkan besarnya simpangan data variabel size selama periode pengamatan.

\section{Uji Asumsi Klasik}

Uji Normalitas

Uji normalitas memiliki tujuan untuk melihat kenormalan distribusi dalam model regresi pada variabel pengganggu atau variabel residual. Uji normalitas penting untuk dilakukan karena jika asumsi klasik dihilangkan, maka uji statistik menjadi tidak valid. Dalam penelitian ini uji normalitas dapat dilihat melalui penyebaran data yang ada pada sumbu diagonal dari grafik dan juga pada besaran nilai KolmogrovSmirnov.

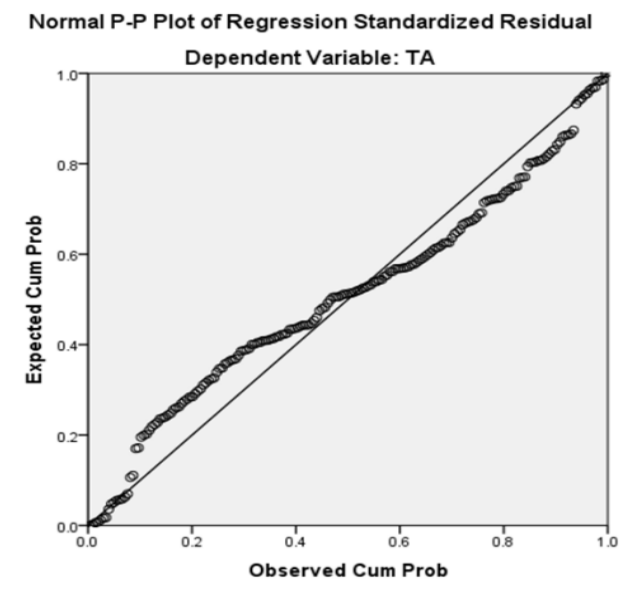

Gambar 1. Uji Normalitas
Berdasarkan gambar 1 dapat dilihat bahwa grafik plot berada disekitar garis dan tidak menjauhi dari garis diagonal. Dengan demikian kesimpulan bahwa data yang digunakan dalam penelitian ini dinyatakan terdistribusi normal dan bisa dilakukan penelitian lebih lanjut.

Table 3. Normality Test One-Sample Kolmogorov-Smirnov

\begin{tabular}{|c|c|c|}
\hline & & $\begin{array}{c}\text { Unstandardized } \\
\text { Residual }\end{array}$ \\
\hline $\begin{array}{l}\mathrm{N} \\
\text { Normal } \\
\text { Parameters }{ }^{\mathrm{a}, \mathrm{b}} \\
\text { Most Extreme } \\
\text { Differences } \\
\text { Kolmogorov-S } \\
\text { Asymp. Sig. (2 }\end{array}$ & $\begin{array}{l}\text { Mean } \\
\text { Std. Deviation } \\
\text { Absolute } \\
\text { Positive } \\
\text { Negative } \\
\text { rnov Z } \\
\text { iled) }\end{array}$ & $\begin{array}{r}192 \\
.0000000 \\
.00932452 \\
.098 \\
.075 \\
-.098 \\
1.352 \\
.052\end{array}$ \\
\hline
\end{tabular}

a. Test distribution is Normal.

b. Calculated from data.

Sumber: Data diolah

Pada tabel 3 menunjukkan pengujian normalitas dengan menggunakan statistik Kolmogrov-Smirnov. Apabila nilai signifikansi $>0,05$ berarti data residual berdistribusi normal, sedangkan apabila nilai signifikansi $<0,05$ berarti data residual tidak berdistribusi normal (Ghozali, 2013). Berdasarkan hasil uji normalitas maka dapat disimpulkan bahwa data penelitian yang digunakan dalam penelitian ini berdistribusi normal. Hal ini ditunjukkan dengan nilai Sig (2-tailed) sebesar 0,052 lebih besar dari tingkat signifikansi sebesar 0,05.

\section{Uji Multikolinieritas}

Uji multikolinieritas ini bertujuan untuk mengetahui apakah ada atau tidaknya korelasi antar variabel independen dalam model regresi. Cara umum yang digunakan oleh peneliti untuk uji multikolinieritas adalah dengan melihat nilai Tolerance dan VIF (Variance Inflation Factor). Model regresi seharusnya tidak terjadi korelasi antara variabel independen. Nilai yang dijadikan acuan untuk menunjukkan tidak adanya masalah multikolinieritas adalah nilai Tolerance $>0.10$ atau nilai VIF $<10$ maka tidak terjadi multikolinieritas.

Tabel 4. Uji Multikolinieritas

\begin{tabular}{|c|c|c|c|}
\hline \multicolumn{2}{|c|}{ Model } & \multicolumn{2}{|c|}{ Collinearity Statistics } \\
\hline & & Tolerance & VIF \\
\hline \multirow{5}{*}{1} & ROA & 0,730 & 1,370 \\
\hline & Leverage & 0,778 & 1,286 \\
\hline & Komisaris Independen & 0,937 & 1,067 \\
\hline & $\begin{array}{l}\text { Kepemilikan } \\
\text { institusional }\end{array}$ & 0,931 & 1,075 \\
\hline & SIZE & 0,893 & 1,120 \\
\hline
\end{tabular}

Dependent Variable: TA

Sumber: Data diolah 
Novita Sari et al, Pengaruh Profitabilitas, Leverage, Komisaris Independen, Kepemilikan Institusional, dan Ukuran Perusahaan terhadap Penghindaran Pajak pada Perusahaan Manufaktur yang Terdaftar di Bursa Efek Indonesia pada Tahun 2014-2018

Nilai Tolerance dan VIF yang dihasilkan dalam tabel 4 menunjukkan bahwa variabel bebas dalam model regresi tidak saling berkolerasi. Pada variabel ROA dapat dilihat nilai Tolerance sebesar 0,730 yang berarti > 0,10 dan nilai VIF sebesar 1,370 yang berarti $<10$. Pada variabel leverage dapat dilihat nilai Tolerance sebesar 0,778 yang berarti $>0,10$ dan nilai VIF sebesar 1,286 yang berarti $<10$.Pada variabel komisaris independen dapat dilihat nilai Tolerance sebesar 0,937 yang berarti > 0,10 dan nilai VIF sebesar 1,067 yang berarti $<10$. Pada variabel kepemilikan institusional dapat dilihat nilai Tolerance sebesar 0,931 yang berarti $>0,10$ dan nilai VIF sebesar 1,075 yang berarti $<10$. Pada variabel size dapat dilihat nilai Tolerance sebesar 0,893 yang berarti $>$ 0,10 dan nilai VIF sebesar 1,120 yang berarti $<10$. Maka dapat disimpulkan bahwa tidak terdapat korelasi antara sesama variabel bebas yang terdapat di dalam model regresi dan tidak terdapat multikolinearitas diantara sesama variabel bebas di dalam model regresinya.

\section{Uji Heteroskedastisitas}

Untuk mendeteksi ada atau tidaknya heteroskedastisitas dengan melihat hasil output SPSS melalui grafik scatterplot antara nilai prediksi variabel terikat (dependen) yaitu ZPRED dengan residualnya SRESID

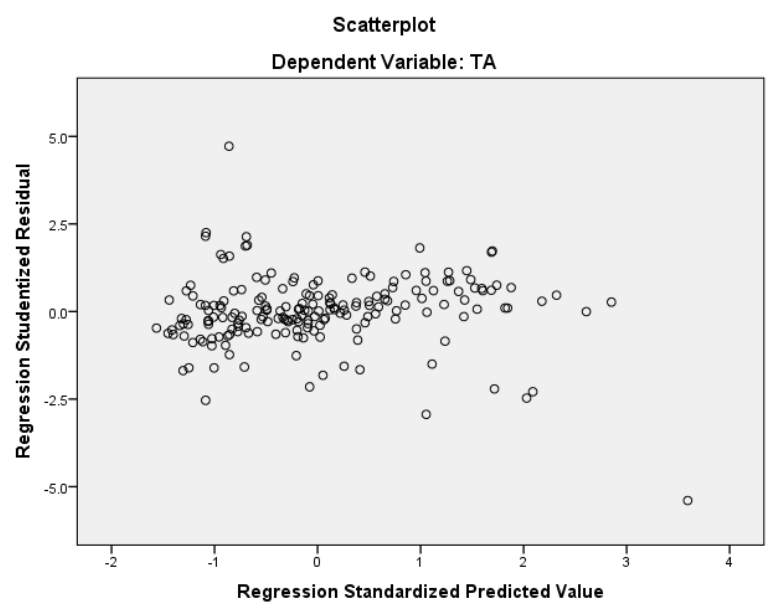

Gambar 2. Uji Heteroskedastisitas

Berdasarkan gambar 2 dapat dilihat bahwa terdapat sebagian titik-titik meentuk pola tertentu. Oleh karena itu, pada penelitin ini membutuhkan uji gletjer untuk mendeteksi apakah terdapat atau tidaknya gejala heteroskedastisitas dalam model regresi yang digunakan. Menurut Ghozali (2013) uji gletjer dilakukan dengan cara meregresikan antara variabel independen dengan nilai absolut residualnya. Jika nilai signifikansi antara variabel independen dengan absolut residual lebih dari 0,05 , maka tidak terjadi masalah heteroskedastisitas. Berikut merupakan hasil uji gletjer.
Tabel 5. Hasil Uji gletjer Coefficients $^{\mathrm{a}}$

\begin{tabular}{|c|c|c|c|c|c|c|}
\hline \multirow{2}{*}{\multicolumn{2}{|c|}{ Model }} & \multicolumn{2}{|c|}{$\begin{array}{c}\text { Unstandardized } \\
\text { Coefficients }\end{array}$} & \multirow{2}{*}{$\begin{array}{c}\text { Standardized } \\
\text { Coefficients } \\
\text { Beta }\end{array}$} & \multirow[t]{2}{*}{$\mathrm{T}$} & \multirow[t]{2}{*}{ Sig. } \\
\hline & & B & Std. Error & & & \\
\hline \multirow{6}{*}{1} & (Constant) & ,010 & ,005 & & 2,069 & ,040 \\
\hline & ROA & ,031 & ,012 & 226 & 2,694 & ,080 \\
\hline & LEV & ,002 & ,001 & 109 & 1,337 & 183 \\
\hline & PDKI &,- 002 & ,008 &,- 015 &,- 206 & ,837 \\
\hline & KI &,- 003 & ,002 &,- 105 & $-1,407$ & 161 \\
\hline & SIZE & ,000 & ,000 &,- 067 &,- 879 & ,381 \\
\hline
\end{tabular}

Sumber: Data diolah

Berdasarkan hasil uji gletjer pada tabel 5, dapat diketahui bahwa nilai signifikansi kelima variabel independen berada diatas 0,05. Dengan demikian dapat disimpulkan bahwa tidak terjadinya gejala heteroskedastisitas pada model regresi, sehingga model regresi layak digunkan.

\section{Uji Autokolerasi}

Uji ini muncul karena observasi yang berurutan sepanjang waktu berkaitan satu sama lain (Ghozali, 2013). Jika tidak terjadi autokolerasi nilai Durbin Watson (DW) pada perhitungan sampel harus $>d U$ dan <4-dU. Hasil uji Autokorelasi dapat dilihat pada tabel berikut:

Tabel 6. Uji Autokorelasi

\begin{tabular}{ccc}
\hline Model & Std. Error of the Estimate & Durbin-Watson \\
\hline 1 & 0,00945 & 1,991 \\
\hline Sumber:
\end{tabular}

Sumber: Data diolah

Berdasarkan hasil pengujian tabel 6, dapat diketahui bahwa DW adalah sebesar 1,991. Dengan jumlah sampel sebanyak 192 (n) dan jumlah variabel independen sebanyak $5(\mathrm{k}=5)$, maka di peroleh nilai $\mathrm{d}_{\mathrm{L}}$ $=1,7107$ dan $\mathrm{d} U=1,8174$. Kemudian nilai $4-\mathrm{d} \mathrm{L}=$ 2,2893 dan nilai 4-dU $=2,1826$. Dapat dilihat bahwa nilai DW sebesar 1,991> dU dan < 4-dU maka pada pengujian ini tidak terdapat autokorelasi.

\section{Analisis Regresi Berganda}

Berdasarkan hasil perhitungan dengan menggunakan SPSS, maka didapat angka dari konstanta ao 0,000 , koefisien regresi $\beta 1$ untuk profitabilitas (ROA) sebesar $0,234, \beta 2$ untuk leverage $0,000, \quad \beta 3$ untuk proporsi dewan komisaris independen yaitu sebesar $0,024, \beta 4$ untuk kepemilikan insititusional yaitu sebesar 0,005 , dan $\beta 5$ untuk ukuran perusahaan (size) yaitu sebesar 0,000. Hasil analisis regresi linier berganda dengan menggunakan SPSS 20 dapat dilihat pada tabel 7 berikut: 
Novita Sari et al, Pengaruh Profitabilitas, Leverage, Komisaris Independen, Kepemilikan Institusional, dan Ukuran Perusahaan terhadap Penghindaran Pajak pada Perusahaan Manufaktur yang Terdaftar di Bursa Efek Indonesia pada Tahun 2014-2018

Tabel 7. Hasil analisis regresi berganda

\begin{tabular}{|c|c|c|c|c|}
\hline \multirow{2}{*}{\multicolumn{2}{|c|}{ Model }} & \multicolumn{2}{|c|}{$\begin{array}{l}\text { Unstandardized } \\
\text { Coefficients }\end{array}$} & \multirow{2}{*}{$\begin{array}{c}\text { Standardized } \\
\text { Coefficients } \\
\text { Beta }\end{array}$} \\
\hline & & B & Std. Error & \\
\hline \multirow{4}{*}{1} & (Constant) & 0,000 & 0,006 & \\
\hline & ROA & 0,226 & 0,015 & 0,766 \\
\hline & Leverage & 0,000 & 0,002 & $-0,009$ \\
\hline & $\begin{array}{l}\text { Komisaris } \\
\text { independen }\end{array}$ & 0,024 & 0,010 & 0,107 \\
\hline
\end{tabular}

$\begin{array}{llll}\text { Kepemilikan } & 0,005 & 0,003 & 0,069 \\ \text { Institusioanl } & & \\ \text { SIZE } & 0,000 & 0,000 & -0,043\end{array}$

a. Dependent Variable: TA

Sumber: Data diolah

Dari tabel 7, maka persamaan regresi dapat ditulis sebagai berikut:

$\mathbf{T A}=0,000+0,226 \mathbf{R O A}+0,000 \mathbf{L E V}+0,024 \mathbf{P D K I}+0,005 \mathbf{K I}+0,000 \mathbf{S I Z E}+\boldsymbol{\varepsilon}$

\section{Pengujian Hipotesis \\ Uji F (Uji Model)}

Tabel 8. Uji F (Uji model)

\begin{tabular}{llrrrrr}
\hline Model & & Sum of & Df & $\begin{array}{r}\text { Mean } \\
\text { Squares }\end{array}$ & F & Sig. \\
& & Square & & \\
\hline \multirow{1}{*}{1} & Regression & 0,028 & 5 & 0,005 & 62,775 & $0,000^{\mathrm{b}}$ \\
& Residual & 0,017 & 186 & 0,000 & & \\
& Total & 0,044 & 191 & & & \\
\hline
\end{tabular}

a. Dependent Variable: TA

b. Predictors: (Constant), SIZE, LEV, KI, PDKI, ROA

Sumber: Data diolah

Dari hasil uji F pada tabel 8 diperoleh $\mathrm{F}$ hitung sebesar 62,775 dan probabilitas sebesar 0,000. Karena sig F hitung < 5\% $(0,000<0,05)$, dapat disimpulkan bahwa profitabilitas, leverage, komisaris independen, kepemilikan institusional, dan ukuran perusahaan secara simultan berpengaruh terhadap tax avoidance atau variabel independen dapat digunakan untuk memprediksi variabel dependen.

\section{Koefisien Determinasi $\left(R^{2}\right)$}

Tabel 9. Uji Determinasi

\begin{tabular}{ccccc}
\hline Model & $\mathrm{R}$ & R Square & $\begin{array}{c}\text { Adjusted } \\
\text { R Square }\end{array}$ & $\begin{array}{c}\text { Std. Error of the } \\
\text { Estimate }\end{array}$ \\
\hline 1 & $0,790^{\mathrm{a}}$ & 0,625 & 0,614 & 0,00945 \\
\hline
\end{tabular}

a. Predictors: (Constant), Size, Leverage, Kepemilikan

Institusional, Komisaris Independen, ROA

b. Dependent Variable: TA

Sumber: Data diolah

Berdasarkan tabel 9 dapat dilihat bahwa besaran nilai $\mathrm{R}^{2}$ adalah 0,614 , hal ini berarti $61,4 \%$ variasi $\operatorname{tax}$ avoidance dapat dijelaskan oleh variasi dari kelima variabel independen yaitu profitabilitas, leveerage, komisaris independen, kepemilikan institusional, dan ukuran perusahaan. Sedangkan sisanya sebesar 38,6\% dapat dijelaskan oleh sebab-sebab yang lain diluar variabel independen. Kemudian besaran nilai Standard Error of Estimate (SEE) adalah 0,00945 yang berarti bahwa semakin kecil nilai SEE akan membuat model regresi semakin tepat dalam memprediksi variabel dependen.

\section{Uji T (Uji Parsial)}

Tabel 10. Hasil Uji T

\begin{tabular}{|c|c|c|c|c|c|c|}
\hline \multirow[t]{2}{*}{ Model } & \multicolumn{2}{|c|}{$\begin{array}{l}\text { Unstandandized } \\
\text { Coefficients }\end{array}$} & \multirow{2}{*}{$\begin{array}{l}\text { Sundardand } \\
\text { Coefficients } \\
\text { Beta }\end{array}$} & \multirow[t]{2}{*}{$\mathrm{T}$} & \multirow[t]{2}{*}{ Sig } & \multirow[t]{2}{*}{ Keterangan } \\
\hline & B & $\begin{array}{l}\text { Std. } \\
\text { Error }\end{array}$ & & & & \\
\hline (Conitant) & 0,001 & 0,006 & & 0,139 & 0,899 & \\
\hline $\mathrm{ROA}$ & 0 & 0,015 & 0,766 & 14,636 & 0,000 & $H_{i} \mathrm{~A}$ \\
\hline Leve: & 0,000 & 0,002 & 0,009 & 0,014 & 0,865 & $\mathrm{H}_{2}$ ditalak \\
\hline $\begin{array}{l}\text { Kornesans } \\
\text { Independen }\end{array}$ & 0,024 & 0,010 & 0,107 & 2,311 & 0,022 & Hij derima \\
\hline $\begin{array}{l}\text { Kepemilkan } \\
\text { Institusicmal }\end{array}$ & 0,005 & 0,003 & 689 & 1,492 & 0,137 & H. Etolak \\
\hline SIZE & 0,000 & 0,000 & $-0,043$ & $-0,907$ & 0,365 & Hs dtolak \\
\hline
\end{tabular}

a. Dependent Variable: TA

Sumber: Data diolah

Uji parsial t dilakukan untuk mengetahui pengaruh secara parsial antara variabel independen yaitu profitabilitas, leverage, komisaris independen, kepemilikan institusional, dan ukuran perusahaan dengan variabel dependen yaitu tax avoidance. Uji ini dilakukan dengan membandingkan nilai signifikansi t dengan tingkat signifikansi (tingkat keyakinan) yang digunakan dalam penelitian ini. Tingkat signifikansi yang digunakan dalam penelitian ini adalah 0,05 . Jika signifikansi $t<0,05$ maka secara individu satu variabel independen berpengaruh terhadap variabel dependen. Jika signifikansi $t>0,05$ maka secara individual satu variabel independen tidak berpengaruh terhadap variabel dependen (Daniel Siahaan 2016).

\section{a. Hipotesis 1}

Berdasarkan tabel 10 dapat disimpulkan hasil pengujian signifikansi menunjukkan terdapat nilai signifikansi ROA sebesar 0,00 $(0,00<0,05)$, dengan nilai beta ROA sebesar 0,766 . Nilai signifikansi dan beta dari ROA menggambarkan bahwa hasil hipotesis pertama dari pengujian profitabilitas terhadap tax avoidance signifikan, sehingga dapat dirumuskan bahwa profitabilitas berpengaruh positif terhadap tax avoidance dan membuktikan bahwa $\mathrm{H}_{1}$ diterima.

\section{b. Hipotesis 2}

Berdasarkan tabel 14 dapat disimpulkan hasil pengujian signifikansi menunjukkan terdapat nilai signifikansi LEV sebesar $0,865 \quad(0,865>0,05)$, dengan nilai beta LEV sebesar $-0,009$. Nilai 
signifikansi dan beta LEV menggambarkan bahwa hasil hipotesis kedua dari pengujian leverage terhadap tax avoidance tidak berpengaruh, sementara pada pengembangan hipotesis menyatakan bahwa leverage berpengaruh positif terhadap tax avoidance, sehingga dapat disimpulkan bahwa bahwa $\mathrm{H}_{2}$ ditolak

c. Hipotesis 3

Berdasarkan tabel 14 dapat disimpulkan hasil pengujian signifikansi menunjukkan terdapat nilai signifikansi PDKI sebesar 0,022 $(0,022<0,05)$, dengan nilai beta sebesar 0,107 Nilai signifikansi dan beta dari PDKI menggambarkan bahwa dewan komisaris independen berpengaruh positif terhadap tax avoidance, hasil pengujian sama dengan pengembangan hipotesis sehingga dapat disimpulkan bahwa $\mathrm{H}_{3}$ diterima.

\section{d. Hipotesis 4}

Berdasarkan tabel 14 dapat disimpulkan hasil pengujian signifikansi menunjukkan terdapat nilai signifikansi KI sebesar 0,137 (0,137>0,05), dengan nilai beta sebesar 0,069 . Nilai signifikansi dan beta menggambarkan bahwa kepemilikan institusional tidak berpengaruh terhadap tax avoidance, sementara pada pengembangan hipotesis menyatakan kepemilikan insttusional berpengaruh negatif terhadap tax avoidance, sehingga dapat dirumuskan bahwa bahwa $\mathrm{H}_{4}$ ditolak.

\section{e. Hipotesis 5}

Berdasarkan tabel 14 dapat disimpulkan hasil pengujian signifikansi menunjukkan terdapat nilai signifikansi SIZE sebesar 0,365 (0,365>0,05), dengan nilai beta sebesar $-0,043$. Nilai signifikansi dan beta menggambarkan bahwa ukuran perusahaan tidak berpengaruh terhadap tax avoidance, sementara pada pengembangan hipotesis menyatakan bahwa ukuran perusahaan berpengaruh negatif terhadap tax avoidance, sehingga dapat dirumuskan bahwa bahwa $\mathrm{H}_{5}$ ditolak.

\section{Pembahasan}

\section{Pengaruh Profitabilitas Terhadap Tax avoidance}

Berdasarkan dari pengujian yang dilakukan hipotesis pertama diterima, jadi dapat disimpulkan bahwa profitabilitas memang berpengaruh positif terhadap tax avoidance.

Profitabilitas merupakan faktor penting untuk pengenaan pajak penghasilan bagi perusahaan, karena profitabilitas merupakan indikator perusahaan dalam pencapaian laba perusahaan. Data dalam penelitian ini menunjukkan rata-rata laba perusahaan cukup besar yaitu 7,6 \% sehingga membayar pajak besar pula. Perusahaan yang memiliki profit tinggi mengindikasikan kecenderungan perusahaan melakukan penghindaran pajak semakin tinggi yang diukur dari semakin kecilnya BTD.
Jadi perusahaan yang memiliki profitabilitas tinggi, berarti semakin tinggi pula pajak yang harus dibayarkan. Beban pajak yang tinggi tersebut akan menurunkan laba perusahaan, sehingga perusahaan akan berusaha melakukan penghindaran pajak untuk menurunkan jumlah pajak yang harus dibayarnya (Zahra, 2017). Hasil penelitian ini sejalan dengan penelitian Darmawan dan Sukartha (2014), Dewi (2017), Subagiastraa et al (2016), Kurniasih dan Ratna Sari (2013), Ayu et al., (2016) Rinaldi and Cheisviyanny (2015).

Hasil temuan penelitian ini mendukung teori keagenan, karena adanya teori keagenan akan memacu para agent untuk meningkatkan laba perusahaan. Ketika laba yang diperoleh membesar, maka jumlah pajak penghasilan akan meningkat sesuai dengan peningkatan laba perusahaan. Agent dalam teori keagenan akan berusaha mengelola beban pajaknya agar tidak mengurangi kompensasi kinerja agent sebagai akibat dari berkurangnya laba perusahaan oleh beban pajak. agent akan memaksimalkan pengelolaan aset internal yang dimilikinya agar mendapatkan kompensasi kinerja dari principal dan insentif yang dapat mengurangi beban pajak (Darmawan and Sukartha, 2014).

\section{Pengaruh Leverage Terhadap Tax avoidance}

Berdasarkan dari pengujian yang dilakukan pada hipotesis kedua $\left(\mathrm{H}_{2}\right)$ diketahui bahwa hasil hipotesis kedua tidak berpengaruh terhadap tax avoidance, sehingga dapat dirumuskan bahwa $\mathrm{H}_{2}$ ditolak. Artinya semakin tinggi leverage tidak akan mempengaruhi aktivitas tax avoidance di perusahaan. Hal itu disebabkan karena semakin tinggi tingkat utang suatu perusahaan, maka pihak manajemen akan lebih konservatif dalam melakukan pelaporan keuangan atau operasional perusahaan. Pihak manajemen akan lebih berhati-hati dan tidak akan mengambil resiko yang tinggi untuk melakukan aktivitas penghindaran pajak guna menekan beban pajaknya. Apabila hutang digunakan dalam jumlah yang besar maka dapat menimbulkan kerugian bagi perusahaan karena harus membayar bunga yang semakin besar (Indriyani, 2017).

Selain itu leverage tidak terbukti secara signifikan mempengaruhi penghindaran pajak yang dilakukan perusahaan. Hal ini dikarenakan kebanyakan perusahaan yang menjadi sampel memiliki nilai hutang jangka panjang yang kecil sehingga hasil peneliti menyatakan bahwa leverage tidak berpengaruh signifikan terhadap penghindaran pajak yang dilakukan perusahaan manufaktur tahun 2014-2018. Dengan demikian hasil penelitian ini tidak sebagaimana mestinya, dimana peneliti tidak menemukan perusahaan dengan tingkat leverage yang tinggi memiliki beban bunga yang tinggi serta resiko penurunan laba yang signifikan, sehingga jika banyak menggunakan hutang dari pihak luar perusahaan, maka laba perusahaan menjadi tidak optimal 
Novita Sari et al, Pengaruh Profitabilitas, Leverage, Komisaris Independen, Kepemilikan Institusional, dan Ukuran Perusahaan terhadap Penghindaran Pajak pada Perusahaan Manufaktur yang Terdaftar di Bursa Efek Indonesia pada Tahun 2014-2018

dan akan berpengaruh terhadap tax avoidance. Hasil penelitian ini juga sejalan dengan Darmawan dan Sukartha (2014), Ayu et al., (2016), dan Moses (2017).

\section{Pengaruh Komisaris Independen Terhadap Tax avoidance}

Berdasarkan dari pengujian yang dilakukan pada hipotesis ketiga $\left(\mathrm{H}_{3}\right)$ diketahui bahwa hasil hipotesis ketiga berpengaruh terhadap tax avoidance, sehingga dapat dirumuskan bahwa $\mathrm{H}_{3}$ diterima.

Positifnya hasil pada hipotesis ketiga dikarenakan kinerja komisaris independen yang seharusnya dapat mengurangi angka penghindaran pajak didalam perusahaan tidak berjalan dengan efektif. Hasil temuan penelitian ini tidak mendukung agency theory, karena berdasarkan agency theory menurut Meckling (1976) terdapat pemisahan antara pemilik dengan pengelola, akan tetapi hasil penelitian menunjukkan peranan pendiri perusahaan sangat dominan dalam menentukan kebijakan perusahaan. Menurut Agoes dan Ardana (2014) kendala yang cukup menghambat kinerja komisaris independen karena sebagian komisaris independen masih lemah dalam kompetensi dan integritasnya. Hal ini terjadi karena pengangkatan komisaris independen sebagian hanya didasarkan atas penghargaan semata, adanya hubungan keluarga (family) atau kenalan dekat (nepotisme). Karena seharusnya komisaris independen adalah anggota dewan komisaris yang diangkat berdasarkan keputusan RUPS dari pihak yang tidak terafiliasi dengan pemegang saham utama, anggota direksi dan/atau anggota dewan komisaris lainnya (Tunggal, 2009). Oleh karena itu seharusnya persyaratan untuk dapat diangkat sebagai komisaris independen sangat ketat, antara lain memiliki integritas dan kompetensi yang memadai agar dapat menunjang kinerja komisaris independen dalam pengawasan. Selain integritas dan kompetensi, komisaris independen juga harus bersifat transparan dan bertanggung jawab baik terhadap pemegang saham maupun kepada pemangku kepentigan (stakeholder) lainnya, yakni masyarakat dan lingkungan. Hal ini juga sesuai dengan hasil penelitian Winata (2014) yang menyatakan bahwa positifnya hasil hipotesis ini menunjukkan bahwa para pemilik perusahaan juga menginginkan pembayaran pajak yang kecil sehingga manfaat yang diterima oleh perusahaan ataupun pemilik perusahaan juga akan semakin besar, tidak menutup kemungkinan bahwa manfaat yang didapat dari praktek tax avoidance ini dapat dimanfaatkan perusahaan untuk membayar kewajiban diluar pajak perusahaan.

\section{Pengaruh Kepemilikan Institusional Terhadap Tax Avoidance}

Berdasarkan dari pengujian yang dilakukan pada hipotesis keempat $\left(\mathrm{H}_{4}\right)$ diketahui bahwa hasil hipotesis keempat tidak berpengaruh terhadap tax avoidance, sehingga dapat dirumuskan bahwa $\mathrm{H}_{4}$ ditolak. Artinya bahwa besar kecilnya kepemilikan institusional tidak membuat praktik tax avoidance yang dilakukan oleh perusahaan tersebut dapat dihindari. Kepemilikan institusional harusnya mampu memainkan peranan penting untuk mengawasi, mendisiplinkan dan mempengaruhi manajer sehingga, dapat memaksa manajemen untuk menghindari perilaku mementingkan kepentingannya sendiri. Akan tetapi, terkonsentrasinya struktur kepemilikan belum mampu memberikan kontrol yang baik terhadap tindakan manajemen atas sikap memenuhi kepentingannya sendiri (Isnanta, 2008). Menurut Fadhilah (2014) dengan ada atau tidaknya kepemilikan institusional kemungkinan dilakukannya tax avoidance akan tetap terjadi. Selain itu, karena pemilik institusional kurang peduli dengan citra perusahaan. Sehingga apapun keputusan manajemen asalkan hal itu bisa memaksimalkan kesejahteraan mereka maka akan didukung. Meskipun keputusan tersebut adalah melakukan tax avoidance.

Selain itu menurut Winning (2018) keberadan struktur kepemilikan institusional tersebut mengindikasikan adanya tekanan dari pihak institusional kepada manajemen perusahaan untuk melakukan kebijakan pajak agresif untuk memaksimalkan perolehan laba untuk investor institusional. Perusahaan memiliki tanggung jawab kepada pemegang saham, maka pemilik instusional memiliki insentif untuk memastikan bahwa manajemen perusahaan membuat keputusan yang akan memaksimalkan kesejahteraan pemegang saham. Pada pengungkapan suka rela menemukan bahwa perusahaan dengan kepemilikan institusional yang lebih besar lebih memungkinkan untuk mengeluarkan, meramalkan dan memperkirakan sesuatu lebih spesifik, akurat dan optimis (Khurana, I. K., 2009).

Hasil temuan penelitian ini tidak mendukung agency theory, karena berdasarkan agency theory menurut Meckling (1976) terdapat pemisahan antara pemilik dengan pengelola, akan tetapi hasil penelitian menunjukkan peranan pendiri perusahaan sangat dominan dalam menentukan kebijakan perusahaan. Kepemilikan institusional yang bertindak sebagai pihak yang memonitor perusahaan belum tentu mampu memberikan kontrol yang baik terhadap tindakan manajemen atas oportunistiknya dalam melakukan praktik tax avoidance. Hal ini dapat disebabkan oleh kualitas sumber daya dari pemilik institusional yang masih kurang. Pemegang saham institusi tidak menjalankan wewenangnya dengan benar dalam mengawasi serta mengontrol keputusan yang diambil oleh manajer sehingga tax avoidance tetap terjadi. Jadi dapat disimpulkan bahwa kepemilikan institusional sebagai pihak yang bertanggung jawab untuk memonitor dan mengontrol pihak manajemen yang sudah diberi hak untuk membuat kebijakan yang memaksimalkan kesejahteraan pemilik, ditambah lagi kepemilikan 
Novita Sari et al, Pengaruh Profitabilitas, Leverage, Komisaris Independen, Kepemilikan Institusional, dan Ukuran Perusahaan terhadap Penghindaran Pajak pada Perusahaan Manufaktur yang Terdaftar di Bursa Efek Indonesia pada Tahun 2014-2018

institusional yang kurang peduli dengan citra perusahaan, maka keberadaan kepemilikan institusioanal tidak dapat menekan penghindaran pajak yang dilakukan oleh perusahaan.

\section{Pengaruh Ukuran Perusahaan Terhadap Tax Avoidance}

Berdasarkan dari pengujian yang dilakukan pada hipotesis kelima $\left(\mathrm{H}_{5}\right)$ diketahui bahwa hasil hipotesis kelima tidak berpengaruh terhadap tax avoidance, sehingga dapat dirumuskan bahwa $\mathrm{H}_{5}$ ditolak.

Hasil penelitian ini sejalan dengan penelitian yang dilakukan oleh Dewi, dan Jati (2014), Agustina dan Aris, (2016) serta Merslythalia dan Lasmana (2016) yang memiliki hasil penelitian yang sama yaitu ukuran perusahaan tidak berpengaruh pada penghindaran pajak. Sementara itu penelitian ini tidak mendukung teori keagenan, dimana menurut Jansen dan Mackling (1976) teori keagenan menyatakan bahwa perusahaan besar memiliki biaya keagenan yang lebih besar daripada perusahaan kecil, namun hasil penelitian menyatakan bahwa ukuran perusahaan tidak berpengaruh terhadap penghindaran pajak, artinya baik perusahaan besar maupun perusahaan kecil tidak mempengaruhi dalam melakukan praktek tax avoidance (Wijayanti 2017). Hal tersebut dikarenakan perusahaan besar ataupun perusahaan kecil sama-sama patuh untuk tidak melanggar ketentuan perpajakan yang berlaku. Perusahaan tidak ingin mengambil resiko untuk direpotkan dengan proses pemeriksaan atau dikenakan sanksi yang dapat menyebabkan citra perusahaan berdampak buruk dalam jangka panjang. Pengawasan yang dilakukan oleh pihak fiskus tidak hanya pada perusahaan besar tetapi perusahaan kecil juga dapat menarik perhatian fiskus agar mengikuti ketentuan perpajakan yang berlaku dan dikenakan pajak yang sesuai dengan peraturan yang berlaku.

\section{SIMPULAN}

Berdasarkan analisis dan pembahasan hasil pengujian hipotesis yang telah dilakukan, maka diperoleh kesimpulan yaitu:

a. Profitabilitas berpengaruh positif terhadap tax avoidance. Perusahaan yang mampu mengelola asetnya dengan baik akan memperoleh keuntungan dari insentif pajak dan kelonggaran pajak lainnya sehingga perusahaan tersebut akan terlihat untuk melakukan tax avoidance.

b. Hasil uji hipotesis kedua menggambarkan bahwa leverage tidak berpengaruh signifikan terhadap tax avoidance. Hasil ini berbeda dengan pengembangan hipotesis kedua yang menyebutkan bahwa leverage berpengaruh positif terhadap tax avoidance, sehingga dirumuskan bahwa bahwa $\mathrm{H}_{2}$ ditolak. Menurut Kurniasih and Ratna Sari (2013) perbedaaan hasil hipotesis pada $\mathrm{H}_{2}$ dengan pengembangan hipotesis pada $\mathrm{H}_{2}$ dikarenakan semakin tinggi nilai dari rasio leverage, berarti semakin tinggi jumlah pendanaan dari utang pihak ketiga yang digunakan perusahaan dan semakin tinggi pula biaya bunga yang timbul dari utang tersebut. Biaya bunga yang semakin tinggi akan memberikan pengaruh berkurang nya beban pajak perusahaan. Semakin tinggi nilai utang perusahaan maka nilai CETR perusahaan akan semakin rendah (Lanis dan Richardson, 2011).

c. Hasil uji hipotesis ketiga menggambarkan bahwa komisaris independen berpengaruh positif terhadap tax avoidance. Ini berarti keberadaan dewan komisaris independen efektif dalam usaha mencegah tindakan penghindaran pajak.

d. Hasil hipotesis keempat menggambarkan bahwa kepemilikan institusional tidak berpengaruh terhadap tax avoidance. Hasil hipotesis keempat berbeda dengan pengembangan hipotesis keempat yang menyebutkan bahwa kepemilikan institusional memiliki pengaruh negatif terhadap tax avoidance, maka $\left(\mathrm{H}_{4}\right)$ ditolak. Menurut Fadhilah (2014) hasil hipotesis keempat yang tidak berpengaruh ini dikarenakan pemilik institusional kurang peduli dengan citra perusahaan. Sehingga apapun keputusan manajemen asalkan hal itu bisa memaksimalkan kesejahteraan mereka maka akan didukung. Meskipun keputusan tersebut adalah melakukan tax avoidance.

e. Hasil hipotesis kelima menggambarkan bahwa ukuran perusahaan tidak berpengaruh terhadap tax avoidance. Hasil hipotesis kelima berbeda dengan pengembangan hipotesisnya yang menyebutkan bahwa ukuran perusahaan berpengaruh positif terhadap tax avoidance, maka $\left(\mathrm{H}_{5}\right)$ ditolak. Hasil tersebut tidak sejalan dengan pendapat bahwa perusahaan yang besar akan melaporkan kondisinya secara lebih akurat, sehingga manajer yang memimpin perusahaan yang lebih besar akan memiliki kesempatan yang lebih kecil dalam memanipulasi laba dibandingkan dengan manajer di perusahaan kecil Nasution dan Setiawan (2007)

\section{DAFTAR PUSTAKA}

Agusti, W. Y. (2014) 'Pengaruh Profitabilitas, Leverage, dan Corporate Governance Terhadap Tax Avoidance (Studi Empiris Pada Perusahaan Manufaktur yang Terdaftar di BEI Tahun 20092012)', Jurnal Akuntansi, 2(3), pp. 1-32.

Agustina, T. N. and Aris, M. A. (2017) 'Tax Avoidance : Faktor-Faktor yang Mempengaruhinya (Studi Empiris Perusahaan Manufaktur yang Terdaftar di Bursa Efek Indonesia Periode 2012-2015)', Seminar Nasional dan The 4th Call for Syariah Paper, pp. 295-307. Available at: https://publikasiilmiah.ums.ac.id/handle/11617/92 
46? show=full.

Alviyani, Surya, R. A. S. and Rofika (2016) 'Pengaruh Corporate Governance, Karakter Eksekutif, Ukuran Perusahaan, dan Leverage Terhadap Penghindaran Pajak (Tax Avoidance) (Studi Pada Perusahaan Pertanian dan Pertambangan yang Terdaftar di BEI Tahun 2011-2014', Jurnal Online Mahasiswa (JOM) Fakultas Ekonomi, 3(1). Available at: https://jom.unri.ac.id/index.php/JOMFEKON/artic le/view/11930.

Darmawan, I. G. H. and Sukartha, I. M. (2014) 'Pengaruh Penerapan Corporate Governance, Leverage, Return on Assets, dan Ukuran Perusahaan Pada Penghindaran Pajak', E-Jurnal Akuntansi, 9(1), pp. 143-161. Available at: https://ojs.unud.ac.id/index.php/Akuntansi/article/ view/8635.

Dewi, dan N. N. (2017) 'Pengaruh Ukuran Perusahaan, Leverage, Profitabilitas dan Corporate Social Responsibility terhadap Penghindaran Pajak (Tax Avoidance)', E-Jurnal Akuntansi Universitas Udayana, 21(1).

Dewi, N. N. K. and Jati, I. K. (2014) 'Pengaruh Karakter Eksekutif, Karakteristik Perusahaan, dan Dimensi Tata Kelola Perusahaan yang Baik Pada Tax Avoidance di Bursa Efek Indonesia', E-Jurnal Akuntansi, 6(2), pp. 249-260. Available at: https://ojs.unud.ac.id/.

Dewinta, I. A. R. and Setiawan, P. E. (2016) 'Pengaruh Ukuran Perusahaan, Profitabilitas, Leverage, dan Pertumbuhan Penjualan Terhadap Tax Avoidance', E-Jurnal Akuntansi Universitas Udayana, 14(3). Available at: https://ojs.unud.ac.id/index.php/Akuntansi/article/ view/16009/14016.

Dharma, I. M. S., dan P. A. A. (2016) 'Pengaruh Leverage, Intensitas Aset Tetap, Ukuran Perusahaan, Dan Koneksi Politik Terhadap Tax Avoidance', E-Jurnal Akuntansi Universitas Udayana.

Fadhilah, R. (2014) '( Studi Empiris Pada Perusahaan Manufaktur yang Terdaftar di BEI 2009-2011) Oleh: RAHMI FADHILAH PROGRAM STUDI AKUNTANSI UNIVERSITAS NEGERI PADANG Wisuda Periode Maret 2014', Fakultas Ekonomi Universitas Negeri Padang.

Fajar, M., Zulbahridar and Kurnia, P. (2018) 'Pengaruh Profitabilitas, Leverage, dan Corporate Governance Terhadap Tax Avoidance (Studi Empiris Pada Perusahaan Manufaktur yang Terdaftar di Bursa Efek Indonesia Periode 20122014)', Jurnal Online Mahasiswa (JOM) Fakultas Ekonomi, 1(1), p. 43. doi: 10.1017/CBO9781107415324.004.

Ghozali, I. (2013) Aplikasi Analisis Multivariate dengan
Program IBM SPSS 21. Edisi 7. Semarang: Badan Peneribit UNDIP.

Hanafi, M., dan A. H. (2003) Analisis Laporan Keuangan E Revisi. Yogyakarta: UPP AMP YKPN.

Indriyani, L. (2017) 'Pengaruh Profitabilitas, Leverage Dan Ukuran PerusahaanTerhadap Tax Avoidance Perusahaan Manufaktur Sektor Makanan \& Minuman Yang Terdaftar Di BEI 2013-2016', p. 68.

Khurana, I. K., W. J. M. (2009) 'Institutional Ownership and Tax Aggressiveness'.

Kurniasih, T. and Ratna Sari, M. (2013) 'Pengaruh Return on Assets, Leverage, Corporate Governance, Ukuran Perusahaan Dan Kompensasi Rugi Fiskal Pada Tax Avoidance', Buletin Studi Ekonomi, 18(1), pp. 58-66.

Kurniasih, T. and Sari, M. M. R. (2013) 'Pengaruh Return on Assets, Leverage, Corporate Governance, Ukuran Perusahaan Dan Kompensasi Rugi Fiskal Pada Tax Avoidance', Buletin Studi Ekonomi, 18(1), pp. 58-66.

Maharani, I. and Suardana, K. (2014) 'Pengaruh Corporate Governance, Profitabilitas, Dan Karakteristik Eksekutif Pada Tax Avoidance Perusahaan Manufaktur', E-Jurnal Akuntansi, 9(2), pp. 525-539.

Marfirah, D. and SyamBZ, F. (2016) 'Pengaruh Corporate Governance dan Leverage Terhadap Tax Avoidance Pada Perusahaan Manufaktur yang Terdaftar di Bursa Efek Indonesia (BEI) Tahun 2011-2015', Jurnal IlmiahMahasiswa Ekonomi Akuntansi, 1(2), pp. 91-102.

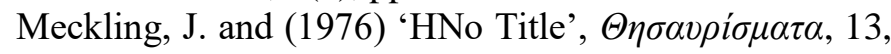
pp. 258-283.

Merslythalia, D. R. and Lasmana, M. S. (2016) 'Komisaris Independen , Dan Kepemilikan Institusional Terhadap Tax Avoidance the Effect of Executive Competency, the Firm Size, the Independent Commisioner and the Institusional Ownership Towards Tax Avoidance', Jurnal Ilmiah Akuntansi dan Bisnis, 11(2), pp. 117-124.

Ngadiman and Puspitasari, C. (2014) 'Pengaruh Leverage, Kepemilikan Institusional, dan Ukuran Perusahaan Terhadap Penghindaran Pajak (Tax Avoidance) Pada Perusahaan Sektor Manufaktur yang Terdaftar di Bursa Efek Indonesia 20102012', Jurnal Akuntansi, XVIII(03), pp. 408-421.

Nursari, M., Diamonalisa and Sukarmanto, dan E. (2017) 'Pengaruh Profitabilitas, Leverage, dan Kepemilikan Institusional terhadap Tax Avoidance (Studi Empiris pada Perusahaan Kimia yang Terdaftar di Bursa Efek Indonesia (BEI) pada Periode Tahun 2009-2016)', Prosiding Akuntansi.

Pohan, H. T. (2016) 'Analisis Pengaruh Kepemilikan 
Institusi, Rasio Tobin Q, Akrual Pilihan, Tarif Efektif Pajak, Dan Biaya Pajak Ditunda Terhadap Penghindaran Pajak Pada Perusahaan Publik', Jurnal Informasi, Perpajakan, Akuntansi, Dan Keuangan Publik, 4(2), p. 113. doi: 10.25105/jipak.v4i2.4464.

Prakosa, B. K. (2014) 'Pengaruh Profitabilitas, Kepemilikan Keluarga dan Corporate Governance Terhadap Penghindaran Pajak Di Indonesia', Simposium Nasional Akuntansi XVII.

Rachmithasari, A. F. (2015) 'Pengaruh Return on Assets, Leverage, Corporate Governance, Ukuran Perusahaan dan Kompensasi Rugi Fiskal Pada Tax Avoidance (Perusahaan Manufaktur yang Terdaftar di Bursa Efek Indonesia Tahun 20112013)'.

Rego, S. O. and Wilson, R. (2011) 'Executive Compensation, Tax Reporting Aggressiveness, and Future Firm Performance', Working Paper, University of Lowa., pp. 1-49.

Rinaldi and Cheisviyanny, C. (2015) 'Pengaruh Profitabilitas , Ukuran Perusahaan Dan Kompensasi Rugi Fiskal Terhadap Tax Avoidance', Seminar Nasional Ekonomi Manajemen dan Akuntansi (SNEMA) Fakultas Ekonomi Universitas Negeri Padang, (c).

Sandy, S. and Lukviarman, N. (2015) 'Pengaruh corporate governance terhadap tax avoidance: Studi empiris pada perusahaan manufaktur', Jurnal Akuntansi \& Auditing Indonesia, 19(2), pp. 85-98. doi: 10.20885/jaai.vol19.iss2.art1.

Sartika, W. (2012) 'Analisis hubungan Penghindaran Pajak Terhadap Biaya Hutang dan Kepemilikan Institusional Sebagai Variable Pemoderasi'.

Sekaran, U. (2011) Metodologi Penelitian untuk Bisnis. Jakarta: Salemba Empat.

Siregar, Rifka, dan . W. (2016) 'Pengaruh Karakteristik Perusahaan terhadap Penghindaran Pajak pada Perusahaan Manufaktur Di BEI', Jurnal Ilmu dan Riset Akuntansi.

Subagiastraa, K., I Putu Edy Arizonab and Mahaputrac, I. N. K. A. (2016) 'Pengaruh Profitabilitas, Kepemilikan Keluarga, Dan Good Corporate Governance Terhadap Penghindaran Pajak (Studi Pada Perusahaan Manufaktur Di Bursa Efek Indonesia)', Jurnal Ilmiah Akuntansi, 1(2), p. 27.

Sukartha, I. M. (2015) 'PENGARUH KARAKTER EKSEKUTIF , KOMITE AUDIT , UKURAN PERUSAHAAN , LEVERAGE DAN SALES GROWTH PADA TAX AVOIDANCE Fakultas Ekonomi dan Bisnis Universitas Udayana, Bali , Indonesia Fakultas Ekonomi dan Bisnis Universitas Udayana, Bali, Indonesia Dari uraian', 1, pp. 47-62.

Sunarsih, U. and Oktaviani, K. (2016) 'Good Corporate Governance in Manufacturing Companies Tax
Avoidance', Etikonomi, 15(2), pp. 85-96. doi: 10.15408/etk.v15i2.3541.

Surbakti, T. A. V. (2012) 'Pengaruh Karakteristik Perusahaan dan Reformasi Perpajakan Terhadap Penghindaran Pajak di Perusahaan Industri Manufaktur yang terdaftar di Bursa Efek Indonesia Tahun 2008-2010', Tesis, p. Universitas Indonesia. Depok. Available at: http://lib.ui.ac.id/file?file=digital/20298969-STheresa Adelina Victoria Surbakti.pdf.

Wijayanti, W. K. and Budi N, A. B. (2017) 'FaktorFaktor Yang Mempengaruhi Total Penerimaan Pajak Negara dan Efektifitas Peraturan Perpajakan', Media Ekonomi, 18(1), pp. 27-40. doi: 10.25105/me.v18i1.53.

Wijayanti, Y. C. and Merkusiwati, N. K. L. A. (2017) 'Pengaruh Proporsi Komisaris Independen, Kepemilikan Institusional, Leverage, dan Ukuran Perusahaan Pada Penghindaran Pajak', E-Jurnal Akuntansi Universitas Udayana, 20(1), pp. 699$728 . \quad$ Available at: https://ojs.unud.ac.id/index.php/Akuntansi/article/ view/29796/19370.

Winata, F. (2014) 'Pengaruh Corporate Governance Terhadap Tax Avoidance Pada Perusahaan Yang Terdaftar Di Bursa Efek Indonesia Tahun 2013', Tax \& Accounting Review, 4 (1)(1), pp. 1-11.

Windarni, N., S., Nurlaela and Suhendro (2018) 'Pengaruh Kepemilikan Institusional, Proporsi Dewan Komisaris Independen, Komite Audit, Pertumbuhan Penjualan dan Leverage terhadap Tax Avoidance', Manajemen, Akuntansi dan Perbankkan.

Zahirah, A., Nurazlina and Rusli (2017) 'Pengaruh Leverage, Kepemilikan Institusional, Kepemilikan Manajerial dan Ukuran Perusahaan Terhadap Penghindaran Pajak (Studi Pada Perusahaan Manufaktur yang Terdaftar di BEI Periode 20132015)', Jurnal Online Mahasiswa (JOM) Fakultas Ekonomi, 4(1). Available at: https://jom.unri.ac.id/.

Zahra (2017) Pengaruh Corporate Governance, Profitabilitas, dan Capital Intensity terhadap Penghindaran Pajak. Universitas Islam Negeri Syarif Hidayatullah.

Zarkasyi, M. W. (2008) Good Corporate Governance Pada Badan Usaha Manufaktur, Perbankan, dan Jasa Keuangan Lainnya. Bandung: Alfabeta. 